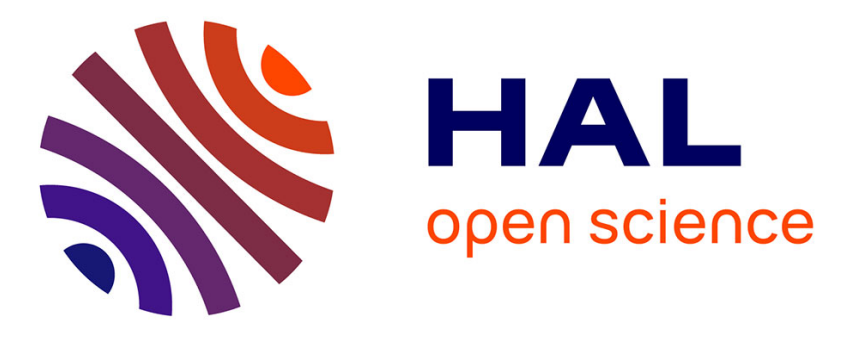

\title{
Viscoelastic characterisation of transparent binders for application on solar roads
}

Domenico Vizzari, Emmanuel Chailleux, Eric Gennesseaux, Stéphane Lavaud, Nadège Vignard

\section{- To cite this version:}

Domenico Vizzari, Emmanuel Chailleux, Eric Gennesseaux, Stéphane Lavaud, Nadège Vignard. Viscoelastic characterisation of transparent binders for application on solar roads. Road Materials and Pavement Design, 2019, pp.S112-S126. 10.1080/14680629.2019.1588774 hal-02080788

\section{HAL Id: hal-02080788 \\ https://hal.science/hal-02080788}

Submitted on 28 May 2021

HAL is a multi-disciplinary open access archive for the deposit and dissemination of scientific research documents, whether they are published or not. The documents may come from teaching and research institutions in France or abroad, or from public or private research centers.
L'archive ouverte pluridisciplinaire HAL, est destinée au dépôt et à la diffusion de documents scientifiques de niveau recherche, publiés ou non, émanant des établissements d'enseignement et de recherche français ou étrangers, des laboratoires publics ou privés. 


\title{
Viscoelastic characterisation of transparent binders for application on solar roads
}

\author{
Domenico Vizzari (1)*, Emmanuel Chailleux, Eric Gennesseaux, Stéphane Lavaud and \\ Nadège Vignard
}

MAST-MIT, IFSTTAR, Nantes, France

(Received 31 October 2018; accepted 22 February 2019)

\begin{abstract}
Polyurethanes are versatile materials and, in civil engineering, they are implemented as bonding elements, injection material to stabilise soil condition, as well as insulating and coating foams. Because of their good adhesion, their transparency, and their mechanical and thermal properties, the idea of the present research is to use it as organic matrix in a glass aggregates/glue composite used as a semi-transparent pavement surface layer. This research takes part in a wider project aiming at designing a hybrid pavement system able to harvest energy from the sun. The aim of this paper is to characterise four different types of thermoset polyurethanes in terms of curing time and visco-elastic properties. For this purpose, an experimental campaign was conducted, performing tests in a dynamic shear rheometer and a dynamic mechanical analysis. Curing time kinetics, defined as the evolution of phase angle, were modelled according to the Arrhenius law. Temperature and frequency dependence on the complex modulus were finally measured. The results demonstrate the strong dependency of the polyurethanes behaviour, overall mechanical performance and especially glass transition temperature, on the curing temperature.
\end{abstract}

Keywords: polyurethane; solar road; dynamic shear rheometer; curing time

3 Original version of the manuscript:

4 https://doi.org/10.1080/14680629.2019.1588774

5

6 Corresponding author: (N. Vignard).

\section{Citation}

E-mail addresses: domenico.vizzari@ifsttar.fr (D. Vizzari), emmanuel.chailleux@ifsttar.fr (E. Chailleux), eric.gennesseaux@ifsttar.fr (E. Gennesseaux), stephane.lavaud@ifsttar.fr (S. Lavaud), nadege.vignard@ifsttar.fr

Domenico Vizzari, Emmanuel Chailleux, Eric Gennesseaux, Stéphane Lavaud \& Nadège Vignard (2019): Viscoelastic characterisation of transparent binders for application on solar roads, Road Materials and Pavement Design, https://doi.org/10.1080/14680629.2019.1588774 


\section{Viscoelastic characterization of transparent binders for application on solar}

2 roads

3 Domenico Vizzari ${ }^{\mathrm{a} *}$, Emmanuel Chailleux $^{\mathrm{b}}$, Eric Gennesseaux ${ }^{\mathrm{c}}$, Stéphane

4 Lavaud $^{\mathrm{c}}$, Nadège Vignard ${ }^{\mathrm{d}}$

$5 \quad{ }^{*}$ PhD Student, MAST-MIT, IFSTTAR, Nantes, France, email: domenico.vizzari@ifsttar.fr

6 domenico06@hotmail.it;

$7 \quad{ }^{b}$ Researcher, MAST-MIT, IFSTTAR, Nantes, France;

$8{ }^{c}$ Engineer, MAST-MIT, IFSTTAR, Nantes, France;

$9{ }^{d}$ Technician, MAST-MIT, IFSTTAR, Nantes, France. 


\section{Viscoelastic characterization of transparent binders for application on solar \\ 2 roads}

3 Abstract

Polyurethanes are versatile materials and, in civil engineering, they are implemented as bonding elements, injection material to stabilize soil condition, as well as insulating and coating foams. Because of their good adhesion, their transparency, and their mechanical and thermal properties, the idea of the present research is to use it as organic matrix in a glass aggregates/glue composite used as a semi-transparent pavement surface layer. This research takes part in a wider project aiming at designing a hybrid pavement system able to harvest energy from the sun.

The aim of this paper is to characterize four different types of thermoset polyurethanes in terms of curing time and visco-elastic properties. For this purpose, an experimental campaign was conducted, performing tests in a dynamic shear rheometer and a dynamic mechanical analysis.

Curing time kinetics, defined as the evolution of phase angle, were modelled according to the Arrhenius law. Temperature and frequency dependence on the complex modulus were finally measured. The results demonstrate the strong dependency of the polyurethanes behaviour, overall mechanical performance and especially glass transition temperature, on the curing temperature.

Keywords: polyurethane, solar road, dynamic shear rheometer, curing time

\section{Introduction}

In the field of energy harvesting, two sources have a good potential for the implementation on road pavements: the solar radiation and the mechanical energy from vehicle loads [Duarte et Ferreira, 2016].

Regarding the solar radiation, it can be directly converted into electricity thanks to solar cells [Agrawal et Prakash, 2017], or it can be exploited in terms of thermal gradient between the road and a heat-transfer fluid pumped into a pipe network, which is imbedded in the asphalt 
2 The present study sets as goal to design and optimize a hybrid system able to exploit both the

3 two sources of the solar radiation [Vizzari et al, 2018]. The idea is to build a prototype 4 composed by the following layers (Fig. 1):

- A semi-transparent top layer made of glass aggregates bonded together through a transparent polyurethane;

- An electrical layer containing the solar cells;

- A porous layer for the circulation of a heat-transfer fluid;

- A waterproof base layer.
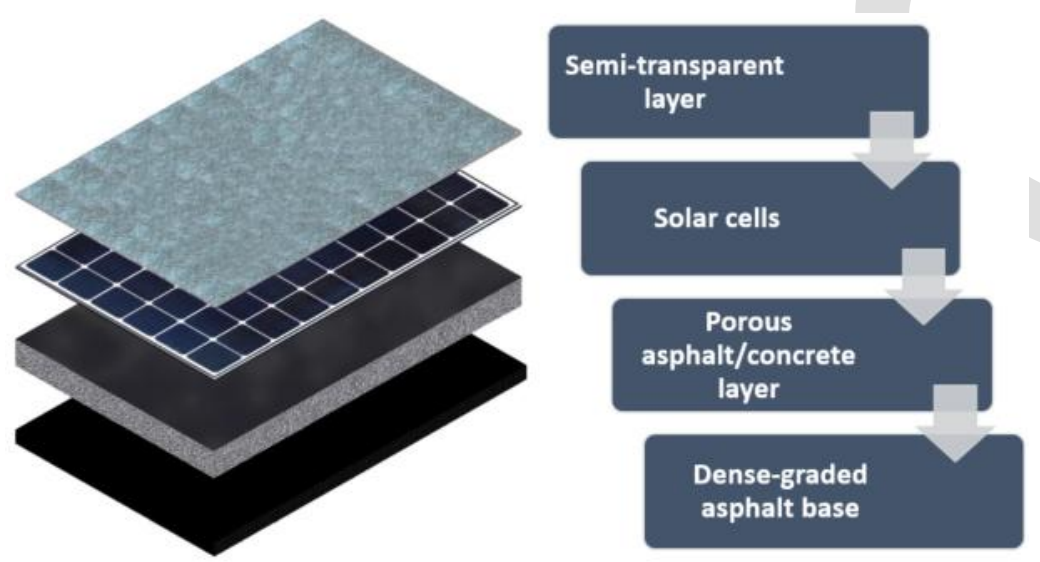

Figure 1. Prototype of a pavement system able to harvest energy from the sun.

The use of the polyurethane as binder for glass aggregates is due to its transparency, its stiffness similar to the bitumen at room temperature and its great adhesion with the glass.

Furthermore, the feasibility of the semi-transparent layer as road surface was demonstrated according to previous tests conducted on a mixture made of glass aggregates and epoxy [Bouron et al, 2017].

In the structure depicted in Fig. 1, the top surface plays a fundamental function. Indeed, it has 
1 to guarantee friction, support the traffic load, protect the solar cells and, at the same time,

2 allow the transmission of sunlight and maximize the heat transfer to the lower layers [Le Touz

3 et al, 2017; Le Touz et al, 2018].

4 The porous layer allows collecting energy thanks to a heat-transfer fluid, as for example the

5 water.

6 It has to be noted that the water can be stored and reused as de-icing system for the road or to

7 heat the buildings nearby [Asfour et al, 2016].

8 Finally, the waterproof base layer prevents any loss of the heat-transfer fluid due to ground 9 infiltration.

As mentioned before, the top layer is a surface composed of glass aggregates bonded together by a glue. Polyurethane glue has been chosen due to its good transparency, good adhesion on glass and its resistance to the sunlight exposition.

The aim of this paper is to characterize four different types of thermoset polyurethanes that will be used as binder of the glass aggregates for the construction of the semi-transparent layer.

\section{Generality about polyurethane glue}

Polyurethanes (PUs) are one of the most versatile and researched materials. Due to their mechanical strength, toughness, good abrasion, corrosion and chemical resistance they have been widely applied in constructions, automotive, textiles, biomedical applications and in several other industries [Akindoyo et al, 2016].

PU are formed by additional polymerization reaction of diisocyanates (containing two or 
2 group) (Fig. 2) [Zafar et Sharmin, 2012].<smiles>O=C=N[Y]N=C=O</smiles><smiles>CC(C)(O)O[Y2]OC(=O)N[Y1]NC(=O)C(C)(C)O</smiles>

\section{Poly(urethane)}

Figure 2. Reaction of diisocyanate with di or poly hydroxy compound [Panda et al, 2018].

Thanks to the variety of diisocyanates and polyols, they can be synthesized for specific applications based on the desired mechanical and chemical properties.

The Tab. 1 lists the main types of polyurethanes:

\begin{tabular}{|c|c|c|c|}
\hline $\begin{array}{c}\text { Type of } \\
\text { polyurethane }\end{array}$ & Properties & Chemistry & Applications \\
\hline Thermoplastic & $\begin{array}{l}\text { Modulable flexibility, } \\
\text { mechanical strength and } \\
\text { elasticity, good abrasion } \\
\text { resistance, and transparency } \\
\text { [Datta et Kasprzyk, 2018] }\end{array}$ & $\begin{array}{l}\text { It is a multi-phase block } \\
\text { copolymer obtained } \\
\text { combining together three } \\
\text { components: i) A polyol } \\
\text { or long-chain diol, ii) a } \\
\text { chain extender or short- } \\
\text { chain diol, iii) a } \\
\text { diisocyanate [Huntsman, } \\
\text { 2010] }\end{array}$ & $\begin{array}{l}\text { Outer cases of electronic } \\
\text { devices, automotive } \\
\text { instrument panels, } \\
\text { medical devices, } \\
\text { sporting goods } \\
\text { [Akindoyo et al, 2016; } \\
\text { americanchemistry.com] }\end{array}$ \\
\hline Flexible & $\begin{array}{l}\text { Long term use } \\
\text { characteristics, } \\
\text { breathability, efficient } \\
\text { manufacturing methods } \\
\text { [Engels et al, 2013] }\end{array}$ & $\begin{array}{l}\text { It is mainly characterized } \\
\text { by a polyol with a high } \\
\text { propylene oxide content } \\
\text { and low ethylene oxide } \\
\text { content ( } 3000-4000 \\
\mathrm{~g} / \mathrm{mol} \text { ) [Engels et al, } \\
2013 \text { ] }\end{array}$ & $\begin{array}{c}\text { Cushion materials, } \\
\text { mattresses, carpet } \\
\text { underlays, automotive } \\
\text { interior parts, packaging } \\
\text { [Kaushiva, 1999] }\end{array}$ \\
\hline Rigid & $\begin{array}{l}\text { Modulable density, low } \\
\text { thermal conductivity } \\
\text { [Engels et al, 2013] }\end{array}$ & $\begin{array}{l}\text { Strongly cross-linked and } \\
\text { close pore material. It is } \\
\text { produced treating } \\
\text { polyether and/or polyester } \\
\text { polyols with polymer } \\
\text { MDI (Methylene diphenyl } \\
\text { diisocyanate) grades } \\
\text { [Engels et al, 2013] }\end{array}$ & $\begin{array}{l}\text { Thermal and sound } \\
\text { insulators } \\
\text { [wernerblank.com] }\end{array}$ \\
\hline
\end{tabular}




\begin{tabular}{|c|c|c|c|}
\hline Ionomers & $\begin{array}{l}\text { Modulable tensile strength } \\
\text { (range from flexible films } \\
\text { to rigid elastomers) } \\
\text { [Ramesh et al, 2008] }\end{array}$ & $\begin{array}{c}\text { It is a specific class of } \\
\text { ion-containing polymers } \\
\text { with less than } 15 \text { mole } \% \\
\text { ionic groups covalently } \\
\text { attached to a hydrocarbon } \\
\text { backbone [Ramesh et al, } \\
2008 \text { ] }\end{array}$ & $\begin{array}{c}\text { Biomedical } \\
\text { applications, polymeric } \\
\text { colorants [Ramesh et al, } \\
2008]\end{array}$ \\
\hline $\begin{array}{c}\text { Water-borne } \\
\text { PU }\end{array}$ & $\begin{array}{l}\text { Excellent adhesion, non- } \\
\text { toxic, thermal, mechanical, } \\
\text { and barrier properties, } \\
\text { decreased gas permeability, } \\
\text { reduced flammability, } \\
\text { improved corrosion } \\
\text { resistance and } \\
\text { thermosetting [Panda et al, } \\
\text { 2018; Honarak, 2018] }\end{array}$ & $\begin{array}{l}\text { It is binary colloidal } \\
\text { system in which the } \\
\text { polyurethane } \\
\text { particles are dispersed in a } \\
\text { continuous aqueous } \\
\text { medium [Honarak, 2018] }\end{array}$ & $\begin{array}{l}\text { Coatings for } \\
\text { various fibers, adhesives } \\
\text { for alternative } \\
\text { substrates, primers for } \\
\text { metals, paint additives } \\
\text { [Zhou et al, 2015] }\end{array}$ \\
\hline
\end{tabular}

Table 1. Types of polyurethanes.

In building and construction materials PUs are applied especially as thermal and sound insulator, in cladding and roofing. They are used as binders in composite structural panels for vehicular and pedestrian bridges [Correia et al, 2012]. In geotechnical engineering, polyurethane injection materials are used to increase load bearing capacity, stabilize soil condition and prevent soil erosion [Yu et al, 2013; Chun et Ryu, 2000]. In road engineering, the recycled polyurethane foam was implemented as bitumen modifier for hot mix asphalt [Salas et al, 2018]. Polyurethanes were also used in modified asphalt, increasing the stability, the low temperature crack resistance and the water damage resistance [Yao et al, 2014]. Terry et al. [Terry et al, 1999] proposed a polyurethane-modified bitumen coating composition for use as moisture barrier for concrete structures.

\section{Materials of the study}

The PUs tested in this paper are obtained by mixing together two components (part $\alpha$ and part $\beta$ ) according to a specific mass fraction (Tab. 2).

The components are mixed separately at the room temperature of $16^{\circ} \mathrm{C}$ during one minute in their aluminium container in order to make the glue fluid and homogeneous. 
1 The two components are then weighted and finally they are manually mixed together for two

2 minutes in a new plastic container, using a lab spoon. The result is a viscous mix, which must

3 be quickly tested before the beginning of the polymerization process.

4 The Tab. 2 summarizes the main properties of the polyurethanes.

\begin{tabular}{|c|c|c|c|c|c|c||}
\hline \multirow{2}{*}{ Ref. } & Part & $\begin{array}{c}\text { Boiling } \\
\text { point } \\
{\left[{ }^{\circ} \mathbf{C}\right]}\end{array}$ & $\begin{array}{c}\text { Flash } \\
\text { point } \\
{\left[{ }^{\circ} \mathbf{C}\right]}\end{array}$ & $\begin{array}{c}\text { Viscosity } \\
{[\mathbf{m P a}]}\end{array}$ & $\begin{array}{c}\text { Density } \\
{\left[\mathbf{g r} / \mathbf{c m}^{3}\right]}\end{array}$ & $\begin{array}{c}\text { Mass } \\
\text { fraction } \\
{[\%]}\end{array}$ \\
\hline \hline \multirow{2}{*}{$\mathbf{A}$} & $\alpha$ & 170 & 220 & $3000\left(20^{\circ} \mathrm{C}\right)$ & 1 & 50 \\
\cline { 2 - 7 } & $\beta$ & NA & 158 & $1200\left(20^{\circ} \mathrm{C}\right)$ & 1.2 & 50 \\
\hline \hline \multirow{2}{*}{ B } & $\alpha$ & 170 & 200 & $700\left(20^{\circ} \mathrm{C}\right)$ & 1 & 47.5 \\
\cline { 2 - 7 } & $\beta$ & 285 & 203 & $1000\left(20^{\circ} \mathrm{C}\right)$ & 1.15 & 52.5 \\
\hline \hline \multirow{2}{*}{$\mathrm{C}$} & $\alpha$ & 200 & 70 & $600\left(20^{\circ} \mathrm{C}\right)$ & 1.3 & 58.7 \\
\cline { 2 - 7 } & $\beta$ & 200 & 200 & $1000\left(20^{\circ} \mathrm{C}\right)$ & 1.13 & 41.3 \\
\hline \hline \multirow{2}{*}{$\mathrm{D}$} & $\alpha$ & 200 & 70 & $700\left(20^{\circ} \mathrm{C}\right)$ & 1.1 & 57.8 \\
\cline { 2 - 7 } & $\beta$ & 231 & 183 & $596\left(20^{\circ} \mathrm{C}\right)$ & 1.15 & 42.2 \\
\hline \hline
\end{tabular}

5

Table 2. Properties of the polyurethanes.

6

4. Experimental Plan

8 For the characterization of the polyurethane binders, an experimental campaign (Fig. 3) was

9 conducted performing the tests by means of the Dynamic Shear Rheometer (DSR) and the

Dynamic Mechanical Analysis (DMA). Both devices enable the measurements of the complex modulus according to linear viscoelasticity theory framework. The complex modulus $\left(\mathrm{G}^{*}\right.$ or $\left.\mathrm{E}^{*}\right)$ is measured in sinusoidal mode of loading in the small strain domain [Ferry, 1980; pavementinteractive.org; Miró et al, 2015]. It is defined as the relationship between complex

14 strain and the complex stress (Eq. 1 and Eq. 2):

or 
1 The complex modulus is given by two components (Eq. 3 and Eq. 4):

$2 G^{*}=G^{\prime}+i G^{\prime \prime}=\left|\mathrm{G}^{*}\right| \exp (\mathrm{i} . \delta) \quad$ in shear mode of loading

$3 E^{*}=E^{\prime}+i E^{\prime \prime}=\left|\mathrm{E}^{*}\right| \exp (\mathrm{i} . \delta) \quad$ in tension-compression mode of loading

4 Where:

5

6

7

8

9

10

$$
\delta=\tan ^{-1}\left(\frac{G^{\prime \prime}}{G^{\prime}}\right)
$$

The DSR was used here to measure the complex shear modulus $\left(\mathrm{G}^{*}\right)$ during the polymerization process of the polyurethanes at one frequency and at constant temperature. The goal was to determine the curing kinetic of the different binders at 50,30 and $10{ }^{\circ} \mathrm{C}$. 
1 The DMA was performed at achieved polymerization, with solid sample, and it provided the

2 complex modulus in tension compression for various frequencies and temperatures. The goal

3 was to determine the curing temperature effect on the mechanical properties of the different

4 glues. Finally the results were compared with the bitumen 35-50, widely used in the asphalt

5 concrete.

6

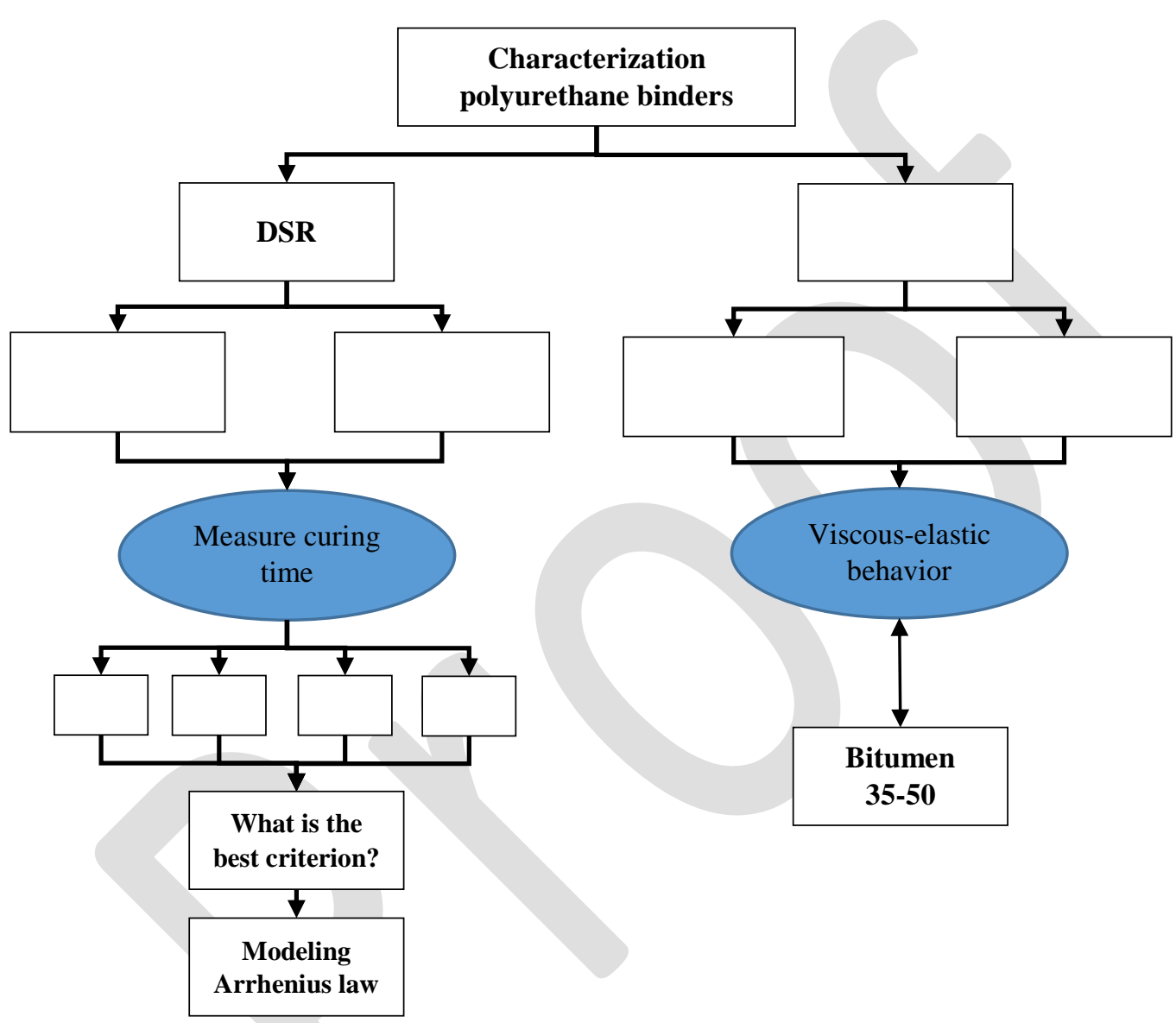

Figure 3. Experimental plan. Legend: $t=$ time; $\delta=$ ratio between the viscous and the elastic components of the complex modulus; $G^{*}=$ complex shear modulus; $T=$ temperature; $E^{*}=$ complex modulus; Crit $=$ Criterion to determine the curing time.

\subsection{Procedure used to determine curing time}

Due to evolution of the glue consistency, from a liquid state to a solid state, a special DSR procedure was used in order to well characterize the curing process. The procedure is carried out under controlled shear stress. Initially the glue behaves like a purely viscous material 
1 (phase angle close to $90^{\circ}$ ). Consequently, the angular displacement can be measured with a

2 good accuracy using a low value of shear stress. However, as the stiffness of the glue

3 increases and the phase angle decreases, the DSR is no more able to provide accurate values

4 of the angular displacement. This is why it is necessary to increase, at this moment, the shear

5 stress.

6 In order to increase the stress according to the glue consistency, an automatic procedure has

7 been developed. It permits to apply a new value of stress each time the measured angle is

8 below a certain value. During the curing of the glue tested here, six values of shear stress has

9 been set: $0.003 ; 0.05 ; 0.1 ; 1 ; 10$ and $100 \mathrm{~Pa}$. The increase of shear stress occurs when the

value of shear strain is less than $1 * 10^{\wedge}-3 \%$ for the stress values of $0.003,0.05$ and $0.1 \mathrm{~Pa}$ and

less than $5^{*} 10^{\wedge}-3 \%$ for the stress values of 1,10 and $100 \mathrm{~Pa}$. In particular, the shear strain values depend on the accuracy limit of the DSR.

The test has been performed for each polyurethane at the temperatures of 50,30 and $10{ }^{\circ} \mathrm{C}$, on $1 \mathrm{~mm}$ thickness samples, placed on a $20 \mathrm{~mm}$ diameter plate-plate system. Complex shear modulus (norm and phase angle) was recorded according to the time at the frequency of $1 \mathrm{~Hz}$. The choice of 50,30 and $10^{\circ} \mathrm{C}$ is to simulate the range temperature in situ, while the frequency of $1 \mathrm{~Hz}$ is a good compromise to obtain acceptable results both in rubbery and glassy state.

\subsection{Procedure used to measure complex modulus}

In order to evaluate the viscous-elastic behaviour of the glues once polymerization was achieved, some cylindrical samples (diameter $8 \mathrm{~mm}$ and height $18 \mathrm{~mm}$ ) were tested. For their manufacturing, the next steps were followed: i) once the part $\alpha$ and the part $\beta$ of the polyurethane were properly mixed, the glue was poured in an elastane mold; ii) the mold was 
1 heated in the oven at a given temperature $\left(50,30\right.$ or $\left.10^{\circ} \mathrm{C}\right)$ until the polymerization process

2 was completed; iii) at achieved polymerization the samples were extracted from the mold and

3 stocked in a room at $20^{\circ} \mathrm{C}$ waiting to be tested using the DMA.

4 The DMA supplies an oscillatory force (tension-compression) which generates a sinusoidal

5 strain. As for the case of DSR, by measuring amplitude ratio and phase lag between

6 sinusoidal stress and strain, complex modulus can be measured [Menard, 1999]. The test was

7 performed under controlled strain for a displacement of $5 \mu \mathrm{m}$ on cylindrical samples

$8 \quad(\mathrm{R}=9 \mathrm{~mm}, \mathrm{~L}=18 \mathrm{~mm})$ at the frequencies of $1 ; 2.2 ; 5 ; 11.2 ; 25 ; 55$ and in a temperature range

9 between 0 and $60^{\circ} \mathrm{C}$.

\section{Results: characterization of polyurethane binders}

\subsection{Curing kinetics}

13 The curing time of the polyurethanes is strictly dependent on the temperature as it can be seen

14 from the evolution of the phase angle for the glue A in the Fig.4. The phase angle reaches low 15 values at very different times based on the curing temperature. For example, at the 16 temperature of $50^{\circ} \mathrm{C}$ the curing time of the glue $\mathrm{A}$ is about 1.5 hours, while at $10^{\circ} \mathrm{C}$ it is more 17 than 40 hours. 




2 Figure 4. Evolution of the phase angle $\delta$ and of complex shear modulus $|G *|$ during the 3 polymerization for the glue A at three different curing temperature.

5 In the literature, the curing time is measured considering the time required for the torque to reach $90 \%$ of the maximum achievable torque [Khimi et Pickering, 2014]. However, since the DSR experiments were carried out here under controlled shear stress, different criteria able to determine the curing time were considered and compared. The criteria are detailed below (the criteria $\mathrm{C} 1$ and $\mathrm{C} 2$ are proposed by the authors, while the criteria $\mathrm{C} 3$ and $\mathrm{C} 4$ derive from the literature):

- $\mathrm{C} 1$ (criterion 1): If the percentage of variation of phase angle $\left(\frac{\delta 1-\delta 2}{\delta 1}\right) .100$ in the time interval $\Delta \mathrm{t}=\mathrm{t}(\delta 2)-\mathrm{t}(\delta 1)$ is less than $5 \%$, then $\mathrm{t}(\delta 2)$ is the curing time of the binder (Fig. 5 - green square);

- $\mathrm{C} 2$ (criterion 2): the curing time is equal to the time corresponding to the minimum value of phase angle: $\mathrm{tc}=\mathrm{t}(\min (\delta))($ Fig. $5-$ red triangle $) ;$

- $\mathrm{C} 3$ (criterion 3) is defined observing the trend of the shear complex modulus with the time. Two behaviours are observable: in the first portion of the curve, $\left|G^{*}\right|$ increases slowly, while in the second it increases more quickly. The curing time 
corresponds to the intersection between the tangents to the two portions of the plot [Ehrenstein et al, 2014] (Fig. 5 - black point);

- $\mathrm{C} 4$ (criterion 4): the curing time is equal to the transition point from a liquid-like state to a solid-like state (gel point) [Nivitha et Krishnan, 2016], which corresponds to $\mathrm{G}^{\prime}=\mathrm{G}{ }^{\prime}$ [Chambon et Winter, 1985] (Fig. 5 - grey rhombus).

(1)



Figure 5. Criteria for evaluation of the curing time (The plot refers to the polyurethane $B$ at the temperature of $30^{\circ} \mathrm{C}$ ). Legend: green square $=$ criterion 1, red triangle $=$ criterion 2, black point $=$ criterion 3 , grey rhombus $=$ criterion 4 )

The Tab. 3 shows all the value of curing time at the temperature of 50,30 and $10^{\circ} \mathrm{C}$ for each polyurethane based on the criteria discussed above:

\begin{tabular}{|c|c|c|c|c|c|c|c|c|c|c|c|c|}
\hline & \multicolumn{10}{c|}{ Curing time [hours] } \\
\hline $\begin{array}{c}\text { Polyu } \\
\text { retha } \\
\text { ne }\end{array}$ & \multicolumn{3}{|c|}{$\mathbf{5 0}{ }^{\circ} \mathbf{C}$} & \multicolumn{3}{|c|}{$\mathbf{3 0}{ }^{\circ} \mathbf{C}$} & \multicolumn{5}{c|}{$\mathbf{1 0}{ }^{\circ} \mathbf{C}$} \\
\hline & $\mathrm{C} 1$ & $\mathrm{C} 2$ & $\mathrm{C} 3$ & $\mathrm{C} 4$ & $\mathrm{C} 1$ & $\mathrm{C} 2$ & $\mathrm{C} 3$ & $\mathrm{C} 4$ & $\mathrm{C} 1$ & $\mathrm{C} 2$ & $\mathrm{C} 3$ & $\mathrm{C} 4$ \\
\hline A & 1.5 & 1.2 & 0.88 & 0.64 & 5.7 & 9.07 & 3.95 & 2.39 & 29.4 & 42.5 & 40.6 & NA \\
\hline B & 3.6 & 3.97 & 2.24 & 1.82 & 13.6 & 15.6 & 7.72 & 6.11 & 50.6 & 63.6 & 45.1 & NA \\
\hline C & 3.4 & 6.11 & 1.9 & NA & 5.3 & 16.1 & 7.94 & NA & 33.6 & 57.8 & 42.1 & 14.8 \\
\hline D & 8.6 & NA & 3.43 & NA & 13.8 & NA & 13.6 & NA & 47.1 & 50.3 & 50.9 & 14.8 \\
\hline
\end{tabular}

Table 3. Curing time of each polyurethane at different temperature based on four criteria.

The limit of the criterion 1 is the arbitrariness of $\Delta \mathrm{t}$, which depends on the speed of polymerization and must be chosen in order to make plausible the $5 \%$ limit of phase angle 

variation.

2 Regarding the criterion 2, it isn't in the cases of poor precision of phase angle measurements.

3 Also the criterion 4 is not always applicable, because some polyurethanes never reach the 4 condition $G^{\prime}=G^{\prime}$, in other terms they show a dominant viscous behavior $\left(G^{\prime \prime}>G^{\prime}\right)$ during all 5 the curing process. In light of this, the most reliable criterion is the number 3.

6 Whatever the tested glue, at the temperature of $10^{\circ} \mathrm{C}$, the curing time ranges between 30 and 760 hours, while at $50^{\circ} \mathrm{C}$ it ranges between 1 and 3.5 hours.

\subsection{Arrhenius law modelling}

$$
k=\Delta e^{-E / R T}
$$
the reaction. error given by:

The temperature influences the speed of a chemical reaction according to the Arrhenius law (Eq. 6) [Laider, 1984]. The equation is given by:

Where: $\mathrm{k}$ is the rate constant $\left(\sec ^{\wedge}-1\right)$ for a reaction of the first order; $\mathrm{E}$ is the activation energy $(\mathrm{J} / \mathrm{mol}), \mathrm{R}$ is the universal gas constant $\left(8.314 \mathrm{~J} / \mathrm{K}^{*} \mathrm{~mol}\right) ; \Delta$ is a pre-exponential factor $\left(\sec ^{\wedge}-1\right)$; $T$ is the temperature $(\mathrm{K})$. In particular the parameters $\mathrm{E}$ and $\Delta$ regulate the speed of

Based on the experimental data summarized in the Tab. 3, the scope was to characterize the curing time of the polyurethanes glue according to the temperature or, in other terms, fit the experimental data of curing time applying the Arrhenius law.

For this purpose, the least square method was applied (Eq. 7). The goal was to minimize the 
$1 \quad$ error $=\sum_{i=1}^{n}\left[z_{i}-\left(k^{-1}\right)_{i}\right]^{2}$

2 Where: zi is the curing time data at the temperature of 50,30 and $10^{\circ} \mathrm{C}$ of the Tab. $3-$ 3 criterion $3 ; \mathrm{k}^{\wedge}-1$ is the multiplicative inverse of the Arrhenius law (Equation 3).

4 The Eq. 4 was minimized changing the parameter $\Delta$ and $\mathrm{E}$ of the Arrhenius law. The Tab. 4 5 and the Fig. 6 show the results:

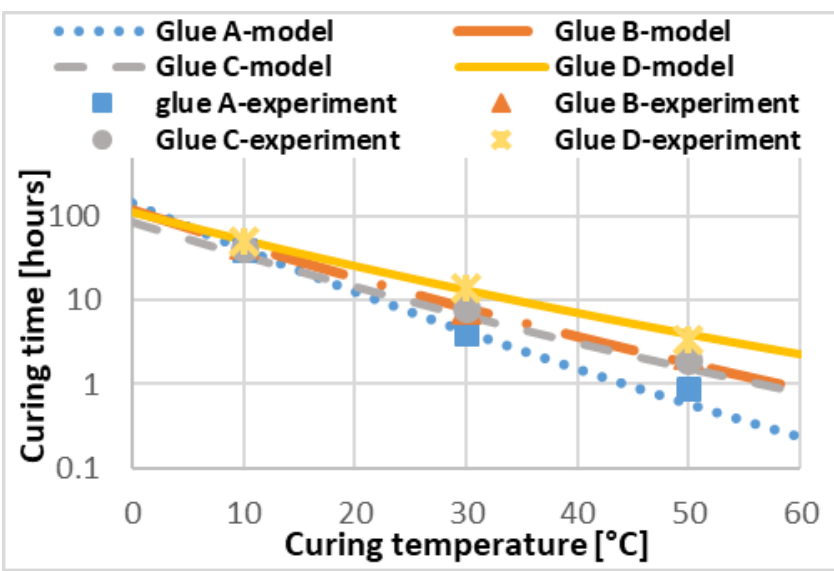

Figure 6. Curing time model vs curing temperature.

\begin{tabular}{|c|c|c|}
\hline $\begin{array}{c}\text { Polyurethane } \\
\text { glue }\end{array}$ & $\begin{array}{c}\boldsymbol{\Delta} \\
{[\mathbf{1} / \mathbf{s e c}]}\end{array}$ & $\begin{array}{c}\mathbf{E} \\
{[\mathbf{J} / \mathbf{m o l}]}\end{array}$ \\
\hline $\mathbf{A}$ & $4.83 \mathrm{E}+09$ & 80445 \\
\hline $\mathbf{B}$ & $1.42 \mathrm{E}+06$ & 61566 \\
\hline $\mathbf{C}$ & $5.75 \mathrm{E}+05$ & 59274 \\
\hline $\mathbf{D}$ & $6.3 \mathrm{E}+03$ & 49126 \\
\hline
\end{tabular}

Table 4. $\Delta$ and $E$ values of the Arrhenius law.

Observing the plot of Fig. 6, the glue A is the faster in terms of curing time, in fact the values $\Delta$ and $\mathrm{E}$ of the Arrhenius law are the highest (Tab. 4). On the contrary, the glue $\mathrm{D}$ is the slowest, according to the values of the parameters $\Delta$ and $\mathrm{E}$.

\subsection{Viscous-elastic behaviour of the polyurethanes}

In order to understand the curing temperature effect on the mechanical properties, samples were heated until the polymerization at the temperatures of 50,30 and $10^{\circ} \mathrm{C}$, during curing time based on the results of the previous section (Arrhenius law). At achieved polymerization, the samples were tested through the Dynamic Mechanical Analysis (DMA). 
2 The effect of the storage time has been firstly assessed considering that post-polymerization 3 process could have an effect on the measurements. Four DMA tests were performed on the

4 glue A, for an initial curing temperature of $50{ }^{\circ} \mathrm{C}$ and for a storage time of $1,2,26$ and 27 5 days in a room at $20^{\circ} \mathrm{C}$.

6 Results are given on the Fig. 7. It was observed a clear relationship between the storage time 7 and the complex shear modulus measured at $1 \mathrm{~Hz}$. In particular, there is a fast evolution of $8\left|\mathrm{G}^{*}\right|$ during the first week of storage. The following measurements will be performed at the 9 same storage time.

\subsubsection{Preliminary tests: effect of storage time}

\section{same storage time.}



Figure 7. Evolution of $\left|G^{*}\right|$ during the storage time for glue A.

\subsubsection{Curing temperature effect on mechanical properties}

In order to evaluate the curing temperature effect on the mechanical properties and to compare glue viscoelastic characteristics, the complex modulus $\left|\mathrm{E}^{*}\right|$ and the phase angle $\delta$ measured at $1 \mathrm{~Hz}$ were plotted according to temperature for each materials manufactured at three curing temperature (Figure 8). The main rheological characteristics which depend on glue nature and curing temperature are the glass transition temperature range and the rubbery 
1

modulus. The glassy modulus remains relatively constant, close to $1 \mathrm{GPa}$. Two types of material can be distinguished. Glue $\mathrm{A}$ and $\mathrm{B}$ show glass transition range between $0^{\circ}$ and $25^{\circ} \mathrm{C}$. Their rubbery moduli are close to $1 \mathrm{e} 7 \mathrm{MPa}$. Glue $\mathrm{C}$ and $\mathrm{D}$ have glass transition for higher temperature, between $40^{\circ} \mathrm{C}$ and $60^{\circ} \mathrm{C}$. Their rubbery moduli tend toward $1 \mathrm{e} 6$. Practically, it means that Glue A and B are close the rubbery state at $30^{\circ} \mathrm{C}$, while Glue $\mathrm{C}$ and $\mathrm{D}$ are in the rubbery state.

Glass transition temperatures $(\mathrm{Tg})$ and viscoelastic properties $\left(\left|\mathrm{E}^{*}\right|\right.$ and phase angle) are given in Table 5 for the four glues and the three curing temperatures. Glass transition temperature is defined as the temperature corresponding to phase angle maximum at $1 \mathrm{~Hz}$ [Kriz et al, 2008]. Calculus is performed after spline interpolation of the phase angle measurements. As it has been already observed on the figures (Fig. 8b, 8d, $8 \mathrm{f}$ and 8h), Glue A and B have lower Tg than Glue C and D. Curing temperature appears to have a non-negligible effect on Tg. Indeed, for all glue, more the curing temperature increases, less is $\mathrm{Tg}$ (around $1{ }^{\circ} \mathrm{C}$ of decrease for $\mathrm{Tg}$ when curing temperature increases by $\left.2^{\circ} \mathrm{C}\right)$. On the other hand, stiffness at $20^{\circ} \mathrm{C}(1 \mathrm{~Hz})$ gives the following ranking (by ascending order): Glue $\mathrm{B}<$ Glue $\mathrm{A}<$ Glue $\mathrm{C}<$ Glue $\mathrm{D}$, whatever the curing temperature. This result has mainly to be attributed to the viscoelastic state of the glues, which are at $20^{\circ} \mathrm{C}$, partly in the glassy state (glue C and D) and partly in the rubbery state (glue A and B). The curing temperature affect also the stiffness measured at $20^{\circ} \mathrm{C}$. The overall behavior shows an increase of the stiffness when the curing time decreases.

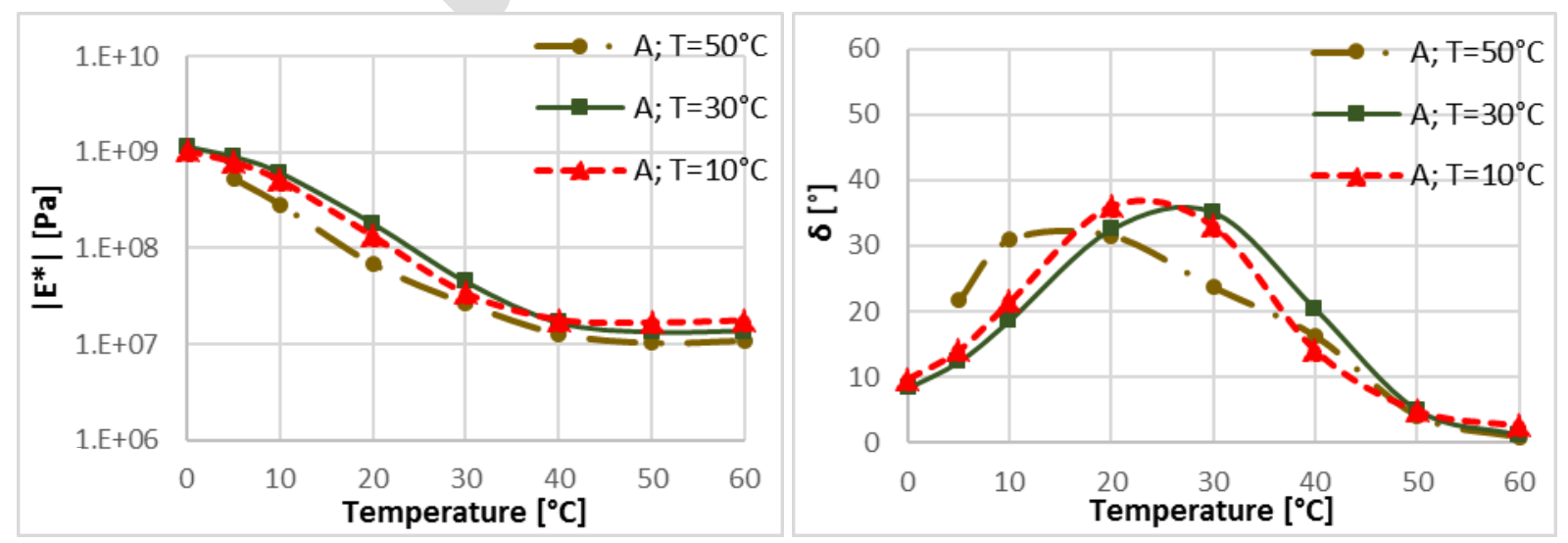





Figure 8. Complex modulus $\left|E^{*}\right|$ and phase angle $\delta$ according to temperature for different curing temperatures at frequency of $1 \mathrm{~Hz}$.

6

\begin{tabular}{|c|c|c|c|c|}
\hline & Glue type & $\mathrm{T}_{\text {cure }}=10^{\circ} \mathrm{C}$ & $\mathbf{T}_{\text {cure }}=30^{\circ} \mathbf{C}$ & $\mathbf{T}_{\text {cure }}=50^{\circ} \mathrm{C}$ \\
\hline \multirow{4}{*}{$\begin{array}{l}\text { Glass transition temperature } \\
\text { (defined as temperature corresponding } \\
\text { to the maximum of phase angle at } 1 \mathrm{~Hz} \text { ) }\end{array}$} & $\mathbf{A}$ & 23.6 & 26.6 & 14.9 \\
\hline & B & 17.7 & 4.7 & $<0$ \\
\hline & $\mathrm{C}$ & $>60$ & $>60$ & 41.5 \\
\hline & D & $>60$ & 42.6 & 39.8 \\
\hline \multirow{3}{*}{$\begin{array}{c}\left|\mathrm{E}^{* \mid}\right|[\mathrm{Pa}] \\
\text { and } \\
\delta\left[^{\circ}\right] \\
\left(\text { at } 20^{\circ} \mathrm{C}, 1 \mathrm{~Hz}\right)\end{array}$} & $\mathbf{A}$ & $\begin{array}{c}1.35^{*} 10^{8} \\
36.1\end{array}$ & $\begin{array}{c}1.81 * 10^{8} \\
32.5\end{array}$ & $\begin{array}{c}6.78 * 10^{7} \\
31.5\end{array}$ \\
\hline & B & $\begin{array}{c}3.33 * 10^{7} \\
38.1\end{array}$ & $\begin{array}{c}1.38 * 10^{7} \\
25.1\end{array}$ & $\begin{array}{c}1.19 * 10^{7} \\
19.9\end{array}$ \\
\hline & C & $\begin{array}{c}1.57 * 10^{9} \\
3.7\end{array}$ & $\begin{array}{c}1.97 * 10^{8} \\
5.9\end{array}$ & $\begin{array}{c}4.53 * 10^{8} \\
17.8\end{array}$ \\
\hline
\end{tabular}


\begin{tabular}{|l|c|c|c|c|}
\hline & D & $1.41 * 10^{9}$ & $5.7 * 10^{8}$ & $5.7 * 10^{8}$ \\
& 4.0 & 15.6 & 18.6 \\
\hline
\end{tabular} 2 glue.

Another useful plot is the Black diagram, which is a representation of the magnitude of the

complex modulus $\left|E^{*}\right|$, versus the phase angle $\delta$. It gives the overall rheological signature of a material [Airey, 2011; Chailleux et al, 2006]. The right part of the graph refers to the case of "high temperatures - low frequencies", while left part to the "low temperatures - high frequencies". Regarding the plots in Fig. 9, the Black curve of the bitumen was introduced for comparison with the Black curves of the polyurethanes. The smooth curve of the bitumen is an indicator of the time-temperature equivalency. In the high frequencies - low temperatures domain, the bitumen exhibits an elastic-like behaviour $\left(0^{\circ}<\delta<20^{\circ}\right)$. At the opposite, in the low frequency-high temperature domain, it behaves like a Newtonian fluid $\left(\delta \approx 90^{\circ}\right)$. Polyurethanes exhibit also a continuous curve in the Black diagram showing they can be considered as thermo-rheologically simple materials. On other word, the macromolecular structure of these polyurethanes remains stable across temperature, without phase changing (except second order phase change like glass transition).

The Black curves referring to the polyurethanes binders never reach the value of $\delta=90^{\circ}$. The reason comes from the cross-linked three-dimensional, covalently-bonded structure of the polyurethanes [Mullins, 2012]. Indeed, these materials are non-fusible after curing. In the domain of low temperatures - high frequencies, all the curves tend to a value of $\mathrm{G}^{*} \approx 1 \mathrm{GPa}$. The polyurethanes are in the glassy state, in fact the phase angle is close to zero degree and the viscous component of the complex modulus is negligible $\left(\mathrm{G}^{*} \approx \mathrm{G}^{\prime}\right)$. This result is a typical value of a polymer in glassy state [Mullins, 2012], confirming the reliability of the tests. Observing the maximum of the Black curves, the first two polyurethanes (A and B) reach a phase angle around $40^{\circ}$, while the other two (C and D) are between 50 and $60^{\circ}$. It has to be 
noted that these values are independent of the initial curing temperature. From an energy point of view, the last two binders have a more dissipative behaviour, which could lead to a greater fatigue resistance and less cracking phenomena.

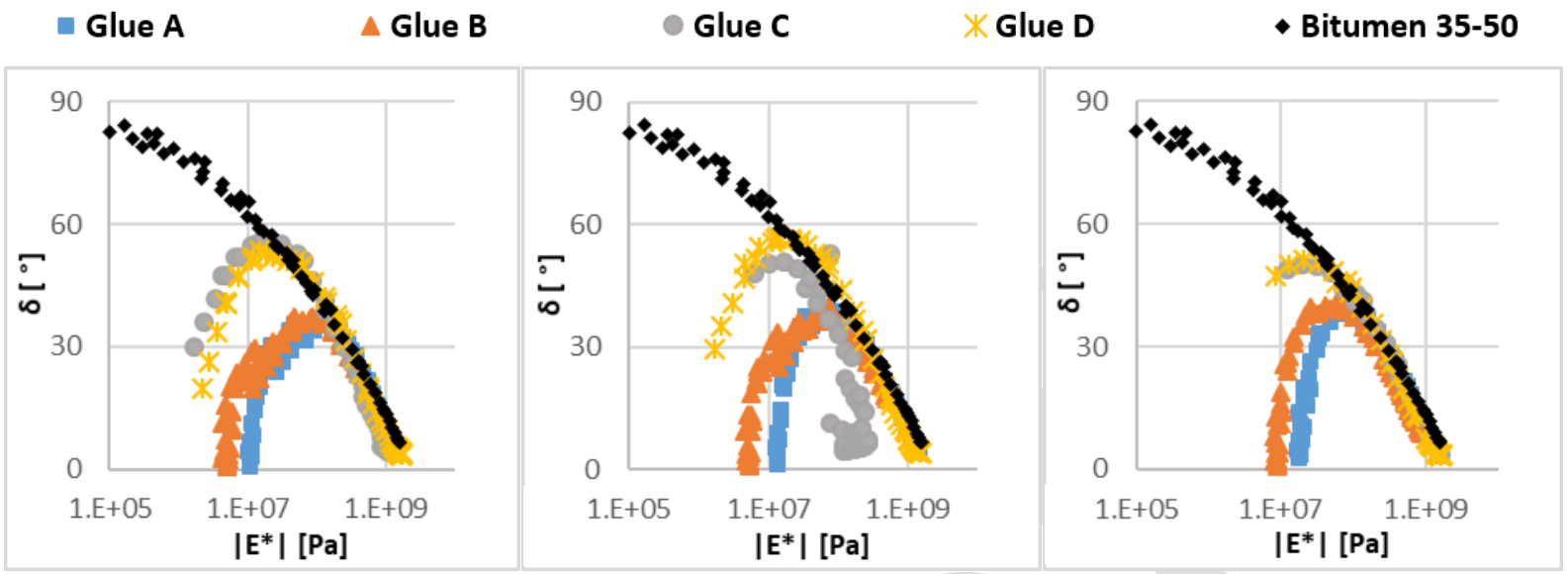

Figure 9. Comparison between the Black curve of a typical bitumen and the Black curves of polyurethanes. 7-A: curing at $50{ }^{\circ} \mathrm{C}$; 7-B: curing at $30^{\circ} \mathrm{C}$; 7-C: curing at $10^{\circ} \mathrm{C}$.

\section{Conclusions}

In this paper, four different types of polyurethanes, good candidate to act as transparent binder for pavement surface mixes, were characterized in terms of curing time and viscous-elastic behaviour. For this purpose, an experimental campaign was conducted performing two types of test: the Dynamic Shear Rheometer and the Dynamic Mechanical Analysis.

The results demonstrated the strong dependency of the curing time on the curing temperature. For example, at the temperature of $10^{\circ} \mathrm{C}$, the curing time ranges between 30 and 60 hours, while at $50^{\circ} \mathrm{C}$ it ranges between 1 and 3.5 hours. The experimental data were modelled according to the Arrhenius law and for each binder an equation was derived. Large differences in curing time were observed for each type of glue with activation energy ranging from $80445 \mathrm{~J} / \mathrm{mol}$ (Glue A) to $49126 \mathrm{~J} / \mathrm{mol}$ (Glue D).

Once the polymerization was achieved, the variation of the complex modulus according to the 
temperature was studied. It was observed that reducing the curing temperature the complex modulus increases (measured at $20^{\circ} \mathrm{C}, 1 \mathrm{~Hz}$ ). This result is mainly due to the position of the glass transition, which is different for each glue. At the temperature of $20^{\circ} \mathrm{C}$, the first two polyurethanes (A and $\mathrm{B}$ ) were in the glass transition range temperature, while the two remaining $(\mathrm{C}$ and $\mathrm{D})$ were in glassy state.

The evolution of the complex modulus with the storage time of the samples was also investigated. The plot showed a quick increase of $\left|G^{*}\right|$ during the first week of storage, probably due to the continuation of the polymerization. Consequently the storage time must be taken into consideration for future researches.

In comparison to conventional bitumen 35-50, the polyurethanes showed the typical behaviour of a thermoset polymer. Indeed, analysing the Black curves, in the domain of high temperatures - low frequencies the polyurethanes never reached the Newtonian state (phase angle of $90^{\circ}$ ). Polyurethanes reach a maximum value of phase angle around $40^{\circ}$ for the glue A and $\mathrm{B}$ and between $50^{\circ}$ and $60^{\circ}$ for the glue $\mathrm{C}$ and $\mathrm{D}$. The right branches of the Black curves (low temperature - high frequency) are very similar both for the bitumen and the polyurethanes.

All these results will be helpful to define the optimized curing conditions and also to determine the link between durability of the transparent mixes according to the linear viscoelastic behaviours of the polyurethanes binders.

\section{Acknowledgments}

The research presented in this paper is part of SMARTI ETN. SMARTI ETN project has received funding from the European Union's Horizon 2020 Programme under the Marie Skłodowska-Curie actions for research, technological development and demonstration, under grant n.721493. 


\section{References}

Agrawal R. and Prakash O.: Feasibility Study of Solar Roadways. Imperial Journal of Interdisciplinary Research (IJIR). Vol-3, Issue-2, 2017.

Airey G. D.: Use of Black Diagrams to Identify Inconsistencies in Rheological Data. Road Materials and Pavement Design. 3:4, 403-424. 2011.

Akindoyo J. O., Beg M. D. H., Ghazali S., Islam M. R., Jeyaratnam N. and Yuvaraj A. R.: Polyurethane types, synthesis and applications - a review. RSC Adv., 2016, 6, 114453.

Asfour S., Bernardin F., Toussaint E. and Piau J.: Hydrothermal modeling of porous pavement for its surface de-freezing. Applied Thermal Engineering, Elsevier, 2016, 107, pp.493 - 500.

Asfour S., Bernardin F., Toussaint E. and Piau J.: Hydrothermal Study of Roads with De-freezing Surface, Obtained by the Circulation of a Warm Fluid in a Bonding Porous Asphalt Layer. $8^{\text {th }}$ RILEM International Symposium on Testing and Characterization of Sustainable and Innovative Bituminous Materials. 2016.

Bobes-Jesus V., Pascual-Munoz P., Castro-Fresno D. and Rodriguez-Hernandez J.: Asphalt solar collectors: A literature review. Applied Energy 102 (2013) 962-970.

Bouron S., Chailleux E., Themeli A., Dumoulin J. and Ropert C.: Revêtement translucide pour la production d'énergie électrique. Revue générale des routes et de l'aménagement (RGRA), No 949, pp. 76-79, Octobre 2017

Chailleux E., Ramond G., Such C. and La Roche C.: A mathematical-based master-curve construction method applied to complex modulus of bituminous materials. Road Materials and Pavement Design, 7:sup1, 75-92. 2006. DOI: 10.1080/14680629.2006.9690059

Chambon F. and Winter H.: Stopping of crosslinking reaction in PDMS polymer at the gel point. Polym Bull 13: 499-503. 1985.

Chun B. and Ryu D.: A Study on Applications of Polyurethane Injection Material for Ground Improvement. Journal of Civil Engineering. Vol. 4, No.2/ June 2000. Page 113 - 118.

Correia J. R., Garrido M., Gonilha J., Branco F. A. and Reis L.: GFRP sandwich panels with PU foam and PP honeycomb cores for civil engineering structural applications. May 2012 International Journal of Structural Integrity 3(2):127-147

Datta J. and Kasprzyk P.: Thermoplastic polyurethanes derived from petrochemical or renewable resources: A comprehensive review. Polymer engineering and science. Volume 58. May 2018.

Duarte F. and Ferreira A.: Energy harvesting on road pavements: State of the art. March 2016. Proceedings of the ICE - Energy 169(2).

Ehrenstein G. W., Riedel G. and Trawiel P.: Thermal analysis of plastics: theory and practice. Chapter 6. Cincinnati: Hanser Gardner Publications. 2004. 
Engels H., Pirkl H., Albers R., Albach R. W., Krause J., Hoffmann A., Casselmann H. and Dormish J.: Polyurethanes: Versatile Materials and Sustainable Problem Solvers for Today's Challenges. Angewandte Reviews. Ed. 2013, 52, 9422-9441.

Ferry J. D.: Viscoleastic properties of polymers. $3^{\text {rd }}$ Edition. 1980.

Honarak H.: Waterborne polyurethanes: A review. Journal of Dispersion Science and Technology. 8, VOL. 39, NO. 4, 507-516. 2018.

http://www.wernerblank.com/polyur/learning/learning_center7.htm

https://polyurethane.americanchemistry.com/Applications/

https://www.pavementinteractive.org/reference-desk/testing/binder-tests/dynamic-shearrheometer/

Huntsman: A guide to the thermoplastic polyurethanes (TPU). 2010.

Kaushiva B. D.: Structure-Property Relationships Of Flexible Polyurethane Foams. Dissertation Submitted to the Faculty of Virginia Polytechnic Institute and State University. August 1999.

Khimi S. A. and Pickering K. L.: A New Method to Predict Optimum Cure Time of Rubber Compound Using Dynamic Mechanical Analysis. J. APPL. POLYM. SCI. 2014.

Kriz P., Stastna J. and Zanzotto L.: Glass Transition and Phase Stability in Asphalt Binders. January 2008. Road Materials and Pavement Design 9(sup1):37-65.

Laider K. J.: The development of the Arrhenius equation. Journal of Chemical Education. 1984.

Le Touz N., Dumoulin J. and Piau J-M.: Solar hybrid road: from concept to modeling and lab scale mock-up experiments. Proceedings of $7^{\text {th }}$ Transport Research Arena TRA 2018, April 16-19, 2018, Vienna, Austria.

Le Touz N., Toullier T. and Dumoulin J.: Infrared thermography applied to the study of heated and solar pavement: from numerical modeling to small scale laboratory experiments. SPIE Thermosense: Thermal Infrared Applications XXXIX, Apr 2017, Anaheim, United States.

Menard K. P.: Dynamic Mechanical Analysis, a Practical Introduction. CRC Press. 1999.

Miró R., Martínez A. H., Moreno-Navarro F. and Rubio-Gámez M.: Effect of ageing and temperature on the fatigue behaviour of bitumens. Materials \& Design Volume 86, 5 December 2015, Pages 129-137.

Mullins M. J.: Mechanical properties of thermosets. 2012.

Nivitha M. R. and Krishnan J. M.: What is Transition Temperature for Bitumen and How to measure it? Transp in Dev. Econ. 2016.

Panda S. S., Panda B. P., Nayak S. K. and Mohanty S.: A Review on Waterborne Thermosetting Polyurethane Coatings Based on Castor Oil: Synthesis, Characterization, and Application. Polymer-Plastics Technology and Engineering. Volume 57, 2018.

Ramesh S., Tharanikkarasu K., Mahesh G. N. and Radhakrishnan G.: Synthesis, Physicochemical Characterization, and Applications of Polyurethane Ionomers: A Review. Polymer Reviews. March 2008. 
Salas M. A., Pérez-Acerbo H., Claderón V. and Gonzalo-Orden H.: Bitumen modified with recycled polyurethane foam for employment in hot mix asphalt. Ingeniería e Investigación vol. 38 n. ${ }^{\circ}$, april - 2018 (60-66).

Terry C. E., Berard R. A. and Pinholster D. F.: Polyurethane-modified bitumen coating composition. United States Patent. Number: 5,981,010. Date: Nov.9, 1999.

Vizzari D., Chailleux E., Lavaud S., and Gennessaux E.: Development of a pavement system able to capture solar energy. JTR 2018. DOI: 10.13140/RG.2.2.10284.56965

Yao Z., Li M., Liu W., Chen Z. and Zhang R.: A Study of polyurethane rubber composite modified asphalt mixture. Advanced Materials Research Vols 941-944 (2014) pp 324-328 Online: 2014-0606. (2014).

Yu L., Wang R. and Skirrow R.: The application of polyurethane grout in roadway settlements issues. GEO Montreal 2013.

Zafar F. and Sharmin E.: Polyurethane: an Introduction. August 2012.

Zhou X., Li Y., Fang C., Li S., Cheng Y., Lei W. and Meng X.: Recent Advances in Synthesis of Waterborne Polyurethane and Their Application in Water-based Ink: A Review. Journal of Materials Science \& Technology 31 (2015) 708-722. 